\title{
研究課題別事後評価結果
}

1. 研究課題名

才ホーツク海水の実態と気候システムにおける役割の解明

2. 研究代表者名及び主たる研究参加者名（研究機関名・職名は研究参加期間終了時点）

\begin{tabular}{|c|c|c|c|c|}
\hline 研究代表者 & 若土 & 正曉 & 北海道大学低温科学研究所 & \\
\hline $\begin{array}{l}\text { 主たる研究参加 } \\
\text { 者 }\end{array}$ & 藤吉 & 康志 & $\begin{array}{l}\text { 北海道大学低温科学研究所 } \\
\text { 月) }\end{array}$ & (平成 10 年 9 月～平成 14 年 10 \\
\hline & 渡邊 & 修一 & $\begin{array}{l}\text { 海洋科学技術センター 主任研究員 } \\
\text { 月) }\end{array}$ & （平成 9 年 11 月～平成 14 年 10 \\
\hline & 郎 & 慶一 & $\begin{array}{l}\text { 北海道大学低温科学研究所 } \\
\text { 月） }\end{array}$ & (平成 9 年 11 月～平成 14 年 10 \\
\hline & 中塚 & 武 & $\begin{array}{l}\text { 北海道大学低温科学研究所 } \\
\text { 月) }\end{array}$ & （平成 9 年 11 月～平成 14 年 10 \\
\hline
\end{tabular}

豊田 威信＼cjkstart北海道大学低温科学研究所 助手（平成 11 年 4 月～平成 14 年 10 月)

3. 研究内容及び成果

北西部大陸棚域を含むオホーツク海のほぼ全域について、ロシアの協力により観測船クロモつを用いた海洋 観測を1998年より3年間実施し、また、2000年の海水拡大期に、ロシア航空機を用いた大気・海水観測を実 施した。研究は海水の消長、海洋循環、物質循環、気団変質、古海洋をそれぞれ分担する研究サブグループか ら成る体制で行われた。

\section{(1) オホーツク海水の消長}

熱収支に重要なオホーツク海水アルベドは、年による水況の違いに関係なくほぼ一定値0.64であった。南 西部海水域は熱源になっており、1日あたりの海水成長量は $0.5 \mathrm{c} \mathrm{m}$ 以下であり、海水の現場生産はわずか で、厚い海水のほとんどは北から運ばれてきたものである。北海道沿岸沖に到達する海水のうち表面が平らな 水盤は、0.2 0.6mのものから成っていた。しかし、これは、あくまで平らな水盤についてであり、才ホー ツク海水は雪を多く含み、さらには水盤ざうしの衝突・重なり合いなど活発な力学過程を経た厚みのある水盤 の割合が圧倒的に多い。

$100 \mathrm{~km}$ 程度、一日以上の時空間スケールでの海水変動を調べると、海水は地衡風とほぼ平行に漂流してお り、季節海水域の大部分における海水漂流速度の日々の変動は、風速場の変動によって説明できる。オホーツ ク海水は北半球で風力係数が最も大きい海域であり、海水域面積の年々変動は北半球の中でも特に大きいが、 風の年による違いによって説明できる。

海水生成量が最も多いのは、北西部のシベリア沿岸域と、樺太沿岸域である。これら沿岸域での海水生成量 はオホーツク海の全海水面積を上まわる。一方、海水域内部では、海水面積の減少も起きており、海水どうし の衝突・重なり合いなどの力学過程がそこで起こっている。力学的に厚くなった海水は、主として南への移流 によって広がっていく。この海水域内での海水面積の減少量だけでも、その合計は才ホーツク海の全海水面積 に匹敵する。これらのことからも、海水が力学的に厚くなる過程は、海水面積変動という観点からも無視でき ない。

\section{（2）オホーツク海の海洋循環}

17地点における流速計係留観測、20基のアルゴス表層ブイ、10数基のPALACE中層フロートを展開した。

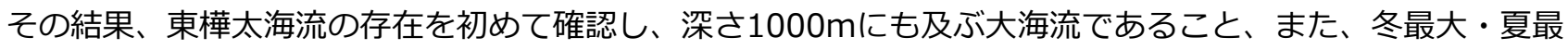
小となる季節変動の大きな海流であることなどを明らかにした。また、西岸境界流（東樺太海流）における密 度流効果はあるものの、ほとんどが冬の北西季節風によって駆動されていることが数值実験の結果から明らか になった。 
オホーツク海中央部から北部海域における反時計回りの循環とそれに伴う西岸境界流（東樺太海流）の存在 が顕著であり、南部の千島海盆域では弱い時計回り循環が卓越し、その内部に100 150kmスケールの高気 圧性渦が数個、ほぼ一定の場所に存在する。

\section{（3）北太平洋中層水起源としての高密度陸棚水生成量の見積もり}

水温・塩分計をつけた係留系観測、すべての歴史データに基づく等密度面データセットの解析、酸素同位体 データ解析など多くの異なる方法により生成量は0.2 0.7Svと見積もられ、方法による違いもあるが、それ 以上に年による違いの大きいことが示された。

\section{（4）ブッソル海峡におけるオホーツク海-北太平洋海水交換}

オホーツク海水の北太平洋への流出は、ほぼブッソル海峡を通じて起こっている。海峡における3ケ所での 2年間にわたる流速計係留観測は成功したが、予想をはるかに越える強烈な潮流のため、充分満足できるデー 夕は取得できなかった。この強力な潮汐流の影響を最小限にするため、係留方式でなく、降下型音響ドップラ 一流速計を用いた観測を2001年度に改めて実施した。その結果、約9Svの才ホーツク海水が太平洋に流出し ていること、また、北太平洋中層水の起源となるオホーツク海水が北海道沖まで達していることが確認され た。

\section{（5）物質循環}

北西部大陸棚域で生成する高密度陸棚水の流出に伴って、大量の高濃度有機炭素が北太平洋の中層に直接運 び込まれることが明らかとなった。また、懸濁粒子有機炭素の炭素同位体比の測定から、北太平洋中層に運び 込まれる有機炭素の起源が、大陸棚上で生産された有機物であることも証明された。才ホーツク海における大 陸棚から外洋への有機炭素の輸送効率は、他の大陸棚域と比べて著しく高く、海氷ブラインによって形成され る高密度水の流出という季節海水域特有のメカ二ズムが、沿岸-外洋系の物質循環過程に大きな影響を及ぼし ている。

オホーツク海は、世界で最も基礎生産力の高い海域の一つとされているが、セジメントトラップ実験から、 特に西部海域の生物生産はアムール河からの淡水供給にコントロールされていることが分かった。

\section{（6）古海洋}

海底堆積物コアの解析から、オホーツク海の生物生産力、特に珪藻の生産は、氷期に低く間水期に高い、極 めて規則的な変化を示したが、これは水期における海水の拡大やアムール河からの栄養塩の流入の減少によっ て生じたものであると考えられる。セジメントトラップ実験から、IRD(Ice Rafted Debris)は、確かに海水の 融解のシグナルであることが分かった。そこで、IRDに見られる海氷の分布は、現在より永期に大きく、 1000年スケールで変動していたこと、融水期に大陸棚から外洋への大規模な物質運搬イベントがあったこ と、融水期－完新世前半（現在よりも温暖期）には、円石藻類が大繁茂し、現在と異なる生態系にあったこ と、などが分かった。

\section{（7）気団変質}

航空機観測により、海水域上における乱流熱フラックスを観測した。沿岸から海水域に入ると、大気は海水 面から、値は小さいが顕熱・潜熱を既に受け取っており、顕熱フラックスの方が潜熱フラックスよりやや大き い。注目すべきは、風下における開水面の存在に対応して、顕熱・潜熱フラックスが共に急激に増大すること である。海水上では既に気団変質が始まっており、雲が発生していることが確認される。また、開水面の上流 の海水域では大気は海水によって冷却されていたが、幅が数 $k m$ 以上の開水面のところで顕熱・潜熱フラック スはそれぞれ50W/m2を超え、大気は急激に加熱された。この大きな乱流熱フラックスは、結果として、凝 結を伴う対流による大気境界層の発達（厚さ）を引き起こすことになる。

オホーツク海高気圧内部領域での観測結果から、オホーツク海高気圧下層には霧が発生し、霧による放射冷 却過程、低温の海水温及び霧による日夎効果の相互作用によって、下層に寒冷な高気圧が形成維持されること などが示された。 
4. 事後評価結果

4 - 1. 外部発表(論文、口頭発表等)、特許、研究を通じての新たな知見の取得等の研究成果の状況

国際的には未踏の才ホーツク海での初めての本格的観測であり、得られたデータに基づく個々の観測事実の 意義は大きい。海水の形成・移動・消滅、厚さを含む海水分布、海水の熱収支における役割、才ホーツク海北 西陸棚域の低温・高密度水の存在の確認、海水を南へ運ぶまぼろしの海流とされていた東樺太海流の構造と季 節変化の把握、オホーツク海北西部で生成された冷水塊が南下した後ブッソル海峡を経て北太平洋中層水とな るという一連のプロセス、海水域上の気団変質過程、12万年間に相当する海底コアの取得による水期・間水 期の変動や1000年スケールでの海水域の拡大・縮小等古気候の復元など多くの新しい知見が得られた。

観測資料の解析は未だ残されており、今後の研究において更に多くの科学的成果が加えられるであろう。 当初の構想に比して「気候システムにおける海水の役割」という視点が薄弱であるが、オホーツク海の海洋 環境の初の組織的総合観測に力を注がざるを得なかつた事情を考慮して本研究の基礎的研究成果を評価してよ い。

投稿済論文17篇を含む41篇がJ.Geophy. Research等有力国際誌に発表されている。 他に特許出願が国内・海外各 1 件ある。

$4-2$. 成果の戦略目標・科学技術への貢献

オホーツク海は地球上で最も低緯度に位置する海水域であり、地球温暖化の影響が顕著に現れる場所でもあ る。また、オホーツク海は北太平洋中層水の起源域であり、二酸化炭素吸収域、高生物生産など物質循環の見 地からも主要な海域である。

ロシアが開放政策をとっている時期にロシアと協力して観測を実施したのは適切であった。北大グループは 「地の利」を生かし、これまでの蓄積を活用して、オホーツク海周辺陸域を含めた環オホーツク環境科学の世 界のセンターに発展する可能性を秘めており、本研究成果はその研究推進へ貢献することが期待できる。

平成12年12月、北大で国際シンポジウム「オホーツク海と周辺陸域における大気一海洋一雪水圏相互作 用」を主催し、20名余の欧米研究者を招聘した。

4 - 3. その他の特記事項（受賞歴など）

特になし。

$\leq<$ 地球変動トップ

This page updated on September 12, 2003 Copyright(C)2003 Japan Science and Technology_Corporation 